\title{
SISTEM MONITORING GANGGUAN BURUNG PADA AREA BANDARA MENGGUNAKAN SISTEM RADAR DAN VISION RECOGNITION
}

\section{MUHAMMAD BENNY CHANIAGO ${ }^{1}$, DANI HAMDANI ${ }^{2}$, ARI PURNO WAHYU ${ }^{3}$}

\author{
1,2,3 Sistem Informasi, Universitas Widyatama \\ Email : benny.chaniago@widyatama.ac.id, dani.hamdani@widyatama.ac.id, \\ ari.purno@widyatama.ac.id
}

\begin{abstract}
ABSTRAK
Saat ini di Indonesia moda transportasi udara merupakan moda transportasi yang cukup banyak dijadikan pilihan oleh masyarakat, salah satu faktor yang mengindikasikannya adalah jumlah kunjungan masyarakat ke bandara dan trafik penerbangan sudah sangat padat sehingga banyak dibuat bandara-bandara baru di beberapa kota di Indonesia. Di bandara banyak sekali permasalahan yang mesti segera diselesaikan berkaitan dengan pelayanan publik sehingga bandara diharapkan dapat memberikan solusi-solusi terhadap permasalahan tersebut dan menjadikan bandara lebih aman serta nyaman. Permasalahan yang sering terjadi di bandara yaitu berkaitan dengan keberadaan burung yang sedang melakukan migrasi dari satu tempat ke tempat lain melintasi kawasan bandara. Banyak kasus terjadi bahwa mesin pesawat jet menabrak dan menyedot burung ke dalam mesin yang berdampak sangat fatal bagi pesawat karena mesin pesawat akan mati. Untuk permasalahan tersebut peneliti melakukan penelitian dengan merancang sistem monitoring gangguan burung pada area bandara menggunakan sistem radar dan vision recognition. Dimana tahapan vision recognition yang digunakan adalah image detection, image acquisition, texture recognition, color recognition dan bird recognition. Dan hasilnya sistem monitoring ini dapat mengidentifikasi keberadaan burung dan membedakannya dengan objek lain, setelah sistem dapat mengetahui keberadaan burung maka alarm akan menyala untuk mengusir keberadaan burung sehingga landasan akan dapat dipastikan aman untuk digunakan pesawat take off dan landing.
\end{abstract}

Kata kunci: Sistem monitoring, burung, pesawat, bandara, sistem radar, vision recognition. 


\section{PENDAHULUAN}

Bandara merupakan area tempat transit sebuah moda transportasi udara dan menjadi gerbang utama sebuah negara. Sistem pengamanan pada area bandara memiliki tingkat keamanan yang tinggi dan dibangun pada lokasi yang strategis. Letak bandara biasanya dibangun pada daerah yang luas dan datar serta jauh dari pemukiman warga. Aspek pembangunan bandara memiliki nilai aspek strategis dilihat dari sisi efisiensi dan teknologi yang digunakan.

Pada bandara lokal hanya bisa disinggahi oleh pesawat berbadan kecil yang biasanya melayani rute domestik, sedangkan sebaliknya pada bandara internasional dilewati pesawat berbadan lebar dan memiliki landasan pacu yang luas. Bandara sendiri terdiri dari beberapa aset yang memiliki nilai yang sangat tinggi, aset tersebut selain fasilitas pendukung yang lengkap juga faktor keamanan sebagai penunjang, baik keamanan penumpang atau proses lalu lalang pesawat itu sendiri.

Sebuah bandara akan melayani lebih dari 40 sorti penerbangan. Hal ini menyebabkan padatnya lalu lintas dan transportasi keluar masuknya pesawat yang melayani rute internasional atapun domestik. Faktor yang paling utama dari sebuah bandara adalah bisa menempatkan pesawat yang baru tiba secara aman pada kondisi landing dan sesudah keberangkatan. Lokasi bandara saat ini rata-rata terletak di wilayah padat seperti di tengah kota dan di daerah padat penduduk, hal ini terjadi jika bandara tersebut merupakan bandara lama yang sebelumnya menggunakan tipe pesawat baling-baling.

Pada saat ini pengembangan moda transportasi udara telah beralih dari mesin baling-baling menjadi mesin Jet. Selain meningkat dari segi kenyamanan dan waktu tempuh yang relatif cepat, pergantian pesawat dari mesin baling-baling ke mesin Jet menimbulkan pula efek negatif yaitu suara mesin yang bising dan getaran yang mengganggu area sekitar. Hal ini menjadi sebuah masalah yang serius ketika bandara baru dibuat dekat dengan area padat dan daerah perlintasan hewan atau satwa asli daerah setempat. Satwa yang paling berbahaya adalah burung yang melintas pada area bandara, burung tersebut bisa masuk atau tersedot pada mesin Jet yang bisa menyebabkan mesin Jet tersebut mati dan membahayakan penumpang. Beberapa peneliti telah melakukan penelitian dan memodifikasi sebuah area bandara, modifikasi tersebut dengan cara memasang jaring pada area bandara dan melakukan penangkaran pada burung yang melintas di bandara. Hal ini tidak selamanya berhasil karena jumlah burung yang terbang di area bandara menjadi bertambah setiap harinya. Masalah ini disebabkan karena insting burung tersebut untuk hidup dan bermigrasi.

\section{LANDASAN TEORI}

Serangan burung atau tabrakan burung adalah sebuah fenomena yang biasa dan sering terjadi pada area bandara, serangan tersebut sering mengganggu penerbangan sipil dan militer. Seorang pilot yang berpengalaman akan menggunakan keahlian dan insting terbangnya untuk menghindari tabrakan tersebut. Tabrakan tersebut terjadi akibat proses migrasi burung yang terkadang melewati area bandara, oleh karena itu beberapa bandara akan melakukan penundaan penerbangan atau delay yang akan menyebabkan kerugian karena menyebabkan jadwal penerbangan menjadi tertunda, sedangkan kecelakaan terjadi biasanya saat kondisi pesawat akan mendarat dan hampir 15 tabrakan menyebabkan kerusakan yang serius pada pesawat (Richardson, W.J. and T. West, 2000) (Desholm, M., et al., 2006).

Bird Strike atau serangan burung adalah sebuah masalah alam yang tidak bisa dihindari. Biasanya tabrakan dengan mesin Jet terjadi pada kecepatan sekitar 150 knot, sedangkan pada kecepatan jelajah menanjak terjadi pada 400 - 450 knot dan pada kecepatan ini lokasi tabrakan 
sering terjadi. Tabrakan pada rute penerbangan dengan kecepatan yang tinggi menyebabkan kerusakan dua kali lebih parah, sedangkan pada burung lokal tabrakan terjadi pada kecepatan yang rendah (Richardson, W.J. and T. West, 2005).

Suatu inovasi baru pernah dicetuskan yaitu bagaimana membuat sebuah sistem anti tabrakan. Sistem tersebut dilakukan dengan pemasangan radar pada area bandara, sistem ini juga dipasang pada wilayah migrasi burung dan sistem radar mampu menampilkan data secara visual (Holleman, I., H. van Gasteren, andW. Bouten,, 2008).

Informasi pergerakan burung pada skala yang lebih besar berguna untuk menampilkan sebuah informasi yang berguna, data tersebut adalah sebuah data migrasi ekologi. Hal ini bisa menyebabkan wabah penyakit yang disebabkan oleh burung, data migrasi tersebut dapat pula digunakan untuk keperluan konservasi dan pendidikan. Pada penelitian sebelumnya sebuah sistem telah dibuat yang digunakan sebagai alat peringatan dini untuk memonitoring migrasi burung, alat tersebut dibuat untuk menjaga sebuah kelangsungan ekosistem burung itu sendiri. Sistem ini mampu melakukan tracking pada burung yang hidup berkelompok. Alat ini dipasang pada area tertentu dan setiap data migrasi akan dianalisis serta berguna sebagai monitoring lingkungan sekitar bandara (Hans van Gasteren;Judy Shamoun-Baranes;Amnon Ginati;Giovanni Garofalo, 2009).

\section{METODE PENELITIAN}

Pada metode pengujian sistem ini dibagi ke dalam tiga tahapan yaitu pengujian sistem radar deteksi burung, pengujian sistem pada aplikasi pengenalan jenis burung yang ada pada area bandara, dan tahapan deteksi dengan radar adalah sebagai berikut :

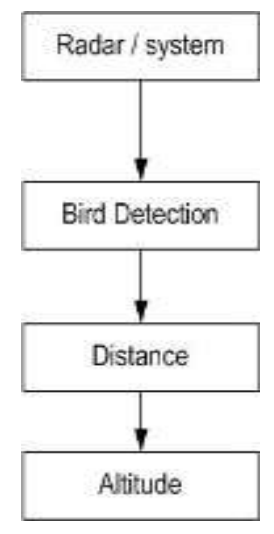

\section{Gambar 1.1 Tahapan Deteksi Sonar Sistem}

Pada gambar 1.1 adalah tahapan sistem peringatan gangguan burung pada sistem kerja radar, radar dipasang pada perlintasan area bandara pada tempat burung tersebut dapat hinggap, radar akan memancarkan sinyal gelombang elektromagnetik secara acak, sistem radar akan menangkap pergerakan burung dan menyimpan posisi lokasi terakhir, data lokasi akan diberi tanda marking dan menampilkanya dalam koordinat jarak (distance) dan ketinggian (altitude). Kedua data tersebut akan ditampilkan secara visual pada radar yang khusus untuk memonitoring migrasi burung yang hanya lewat atau hinggap di area bandara, bagi burung yang terlalu dekat area bandara akan dilakukan sistem pengusiran dengan alarm, sistem ini akan memberikan informasi pada petugas atau pilot untuk mengatur rute take offdan landing.

Pada pengujian sistem yang kedua adalah menggunakan thermal imaging atau recognition system. Sistem ini mengandalkan bantuan kamera, kamera tersebut akan memproses objek 
yang ada di bandara sehingga dapat mengenali objek pesawat atau burung. Sistem ini bekerja secara bersamaan dengan sistem radar, cara kerja sistem recogniton tersebut adalah sebagai berikut :

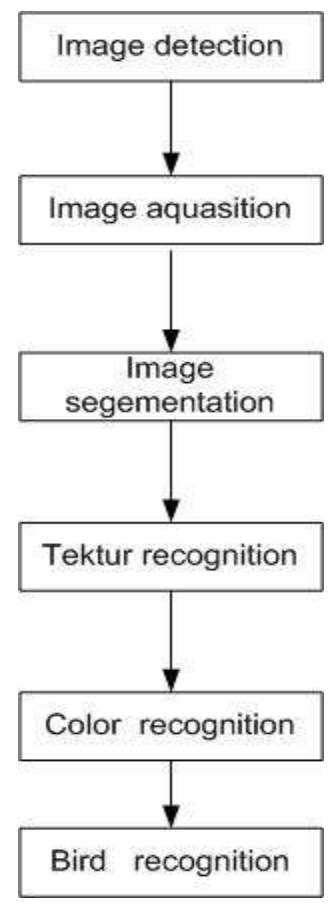

\section{Gambar 1.2 Langkah Deteksi Bird Recognition}

Pada gambar tersebut adalah tahapan deteksi burung dengan bantuan sistem vision recognition. Sistem vision recognition digunakan untuk mengenal objek secara visual dengan membandingkan data yang sudah disimpan sebelumnya dalam sebuah server. Nilai akurasi sistem deteksi tersebut tergantung pada jumlah data training dan data testing yang digunakan. Tahapan vision recognition tersebut adalah sebagai berikut :

\section{- Image Detection}

Pada proses image detection, inputan data tergantung pada jenis kamera yang digunakan, posisi kamera bisa diletakkan secara tersebar sesuai dengan posisi tempat burung tersebut singgah.

\section{- Image Acquisition}

Pada bagian ini proses kalibrasi dilakukan pada alat dan kamera yang digunakan. Hal ini dimaksudkan untuk menentukan besaran pixel agar ditemukan resolusi yang tepat antara kamera dengan posisi objek. Sistem kalibrasi diperlukan pada alat yang ditempatkan dalam kondisi statis dan tidak berpindah tempat.

\section{- Texture Recognition}

Texture recognition adalah teknik dasar dalam menentukan nilai sebuah pola atau bentuk objek. Objek yang digunakan di sini adalah objek jenis burung yang biasa melintas atau hinggap di area bandara. Sistem ini dibuat pintar sehingga bisa mengenali jenis objek burung yang berbeda-beda sesuai dengan data yang tersimpan pada database. Dataset diambil berdasarkan karakteristik burung yang bisa dilihat dari jenis paruh, rentang sayap serta bentuk badan. 


\section{- Color Recognition}

Pada bagian ini dilakukan sistem sortasi warna. Warna diambil dari semua jenis burung yang ada di area bandara, warna tersebut akan menjadi kombinasi penting dan unik untuk membedakan burung serta objek yang lain.

\section{- Bird Recognition}

Pada bagian ini adalah tampilan akhir dari output system. Output yang dihasilkan berupa tanda marking dengan perbandingan nilai akurasi objek yang dideteksi.

\section{IMPLEMENTASI SISTEM}

Pada implementasi pengujian sistem dibagi ke dalam beberapa tahapan, pertama pengujian dengan sistem radar dan yang kedua pengujian dengan teknik vision recognition. Teknik penggabungan memungkinkan pembacaan data memiliki nilai akurasi yang tinggi.

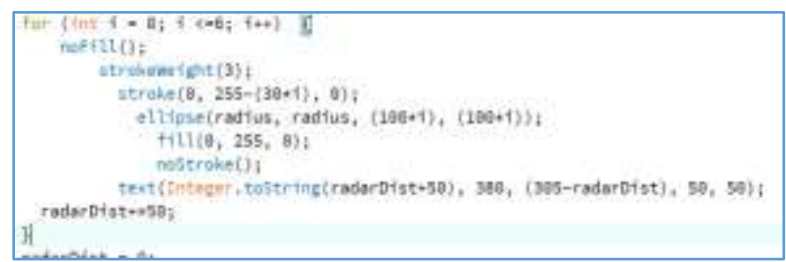

\section{Gambar 1.3 Source Code Pengaturan Daya Pancar Radar}

\section{Keterangan :}

Pada gambar 1.3 adalah sistem pengaturan daya pancar radar yang dipasang pada area bandara. Pengaturan jarak pancar diatur dalam sebuah sudut putaran yang diatur hingga $360^{\circ}$.

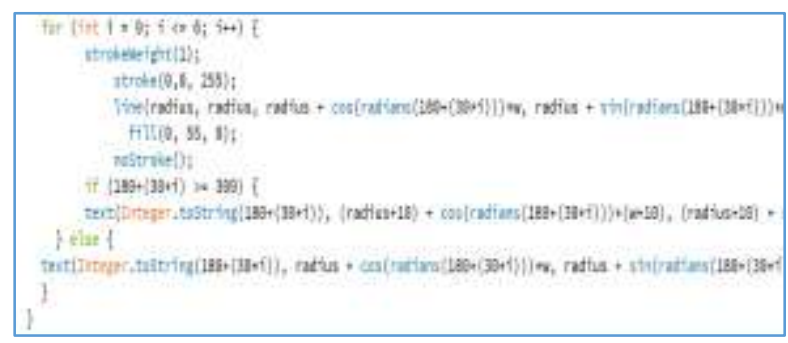

Gambar 1.4 Source Code Pengaturan Tampilan Visual Radar

\section{Keterangan :}

Pada gambar 1.4 adalah pengaturan visual tampilan pada layer. Source code tersebut mengatur lebar layar radar, warna radar serta tampilan visual jarak objek yang terdeteksi. 


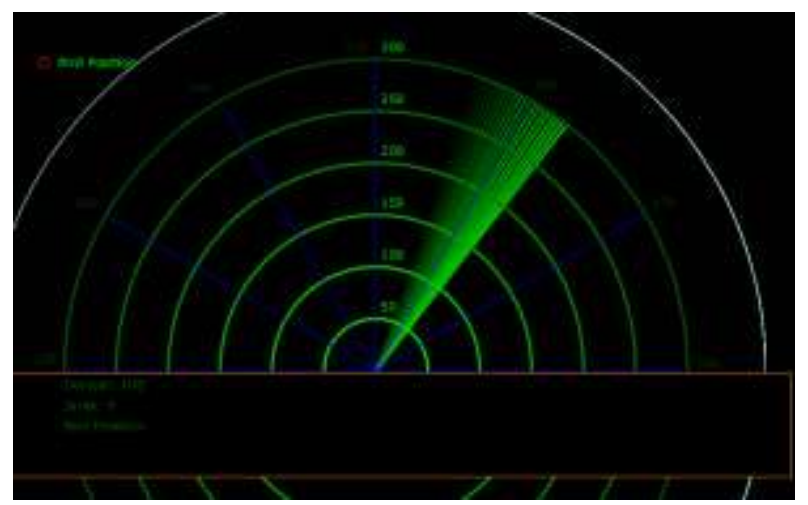

\section{Gambar 1.5 Tampilan Visual Radar Normal}

\section{Keterangan :}

Pada gambar 1.5 adalah proses uji coba radar dalam kondisi normal yang dipresentasikan dengan indikator pantulan warna, pada tampilan jarak pantulan diatur 5 hingga $10 \mathrm{~km}$. Warna hijau merupakan simbol pantulan radar dalam kondisi normal dan tidak ada objek yang terdeteksi.

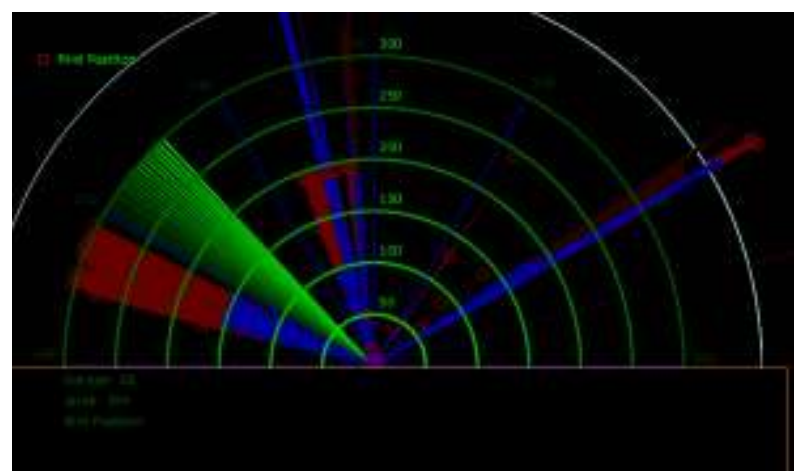

\section{Gambar 1.6 Tampilan Visual Radar Mendeteksi Burung}

\section{Keterangan :}

Pada gambar 1.6 adalah hasil uji coba yang menunjukan radar mendeteksi objek yang terbang dengan indikator berwarna merah dan terdapat tanda marking ' 0 ' (lingkaran). Objek tersebut diindikasikan sebagai burung yang terbang secara berkelompok atau migrasi, data migrasi tersebut bisa digunakan sebagai referensi pergantian jalur penerbangan atau pengamanan area landasan sebelum dilakukan take off dan landing. 


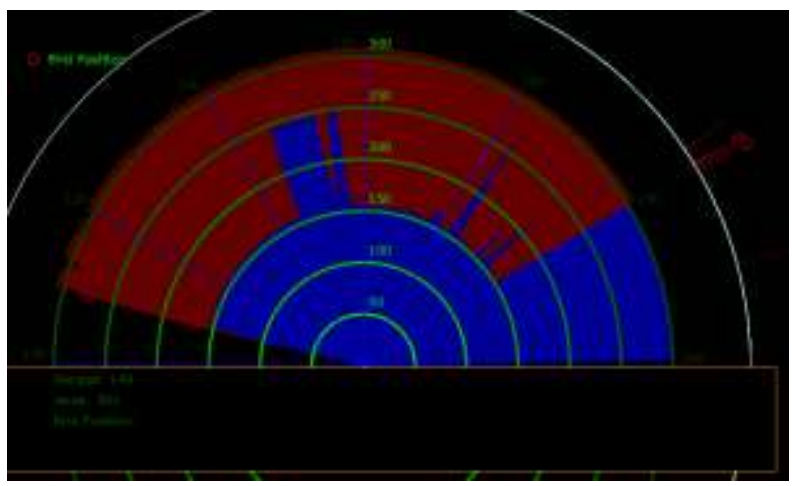

\section{Gambar 1.7 Tampilan Visual Radar Mendeteksi Burung Bermigrasi}

\section{Keterangan :}

Pada gambar 1.7 adalah sistem deteksi radar yang menunjukan burung mulai melintasi area bandara dan zona penerbangan. Proses selanjutnya dilakukan pengusiran dengan mengaktifkan alarm atau perubahan zona penerbangan.

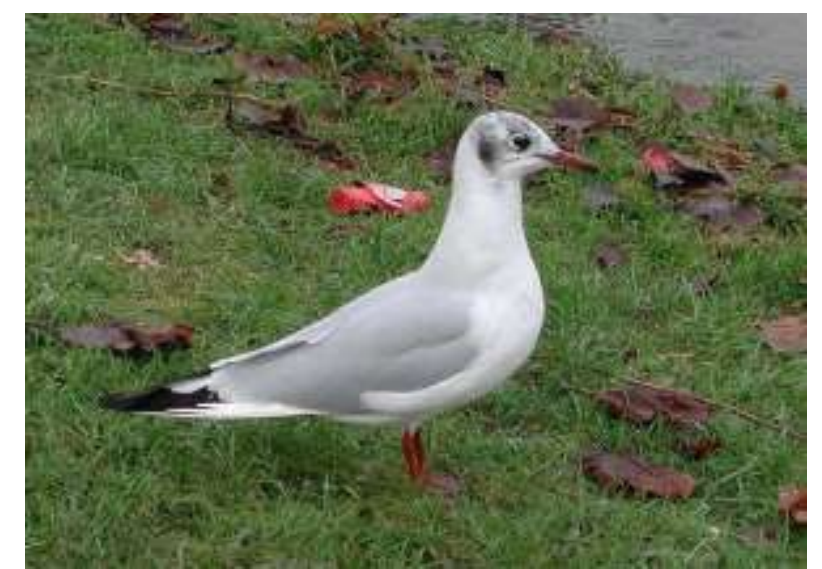

Gambar 1.8 Uji Coba Sample Jenis Burung

\section{Keterangan :}

Pada gambar 1.8 adalah sistem pembacaan objek yang sudah mengenali jenis burung. Data akan menampilkan jenis burung secara visual. Teknik pengenalan pola atau image recognition, pola gambar diambil dari data fitur bentuk paruh, rentang sayap dan warna burung. Tiap data disimpan dalam database yang nantinya digunakan untuk membandingkan dengan gambar realtime jenis burung yang ada di lapangan. Sistem tidak akan salah mengenali objek burung dengan objek lain atau pesawat di area bandara karena telah ditambah dengan fitur pengenalan pola. 


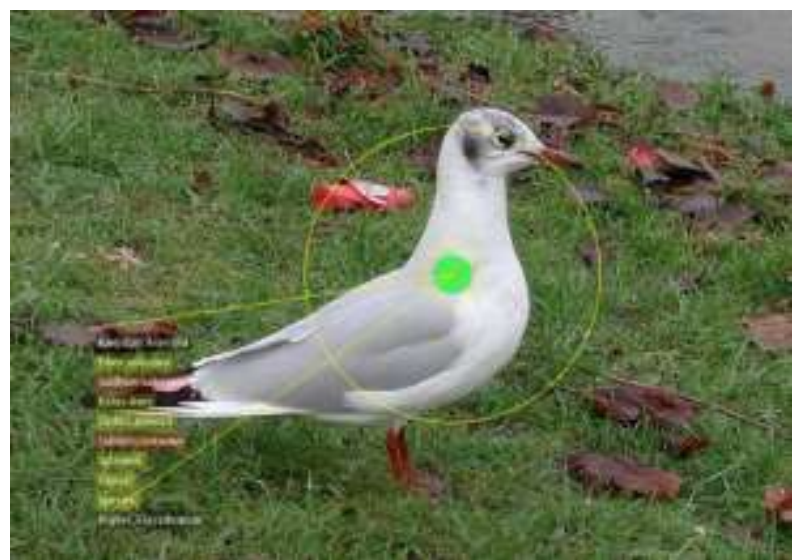

Gambar 1.9 Tampilan Visual Image Recognition

\section{Keterangan :}

Pada gambar 1.9 adalah hasil pengenalan fitur burung yang dibaca dengan teknik image recognition. Pada tampilan visual sistem memberikan sebuah tanda marking pada objek, tanda visual tersebut berupa keterangan jenis burung dan keterangan habitatnya.

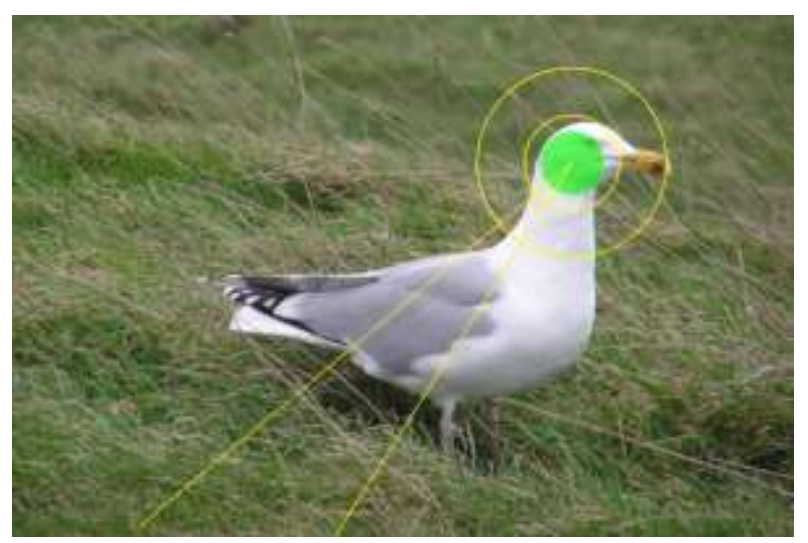

\section{Gambar 1.10 Tampilan Visual Radar Mendeteksi Burung Bermigrasi}

\section{Keterangan :}

Pada gambar 1.10 adalah sistem pengenalan jenis burung yang dilihat pada bagian paruh dan kepala. Sistem mengubah data tersebut ke dalam sebuah format atau pola dan warna, perbandingan data dibaca menggunakan image recognition sesuai dengan dataset yang ada pada sistem.

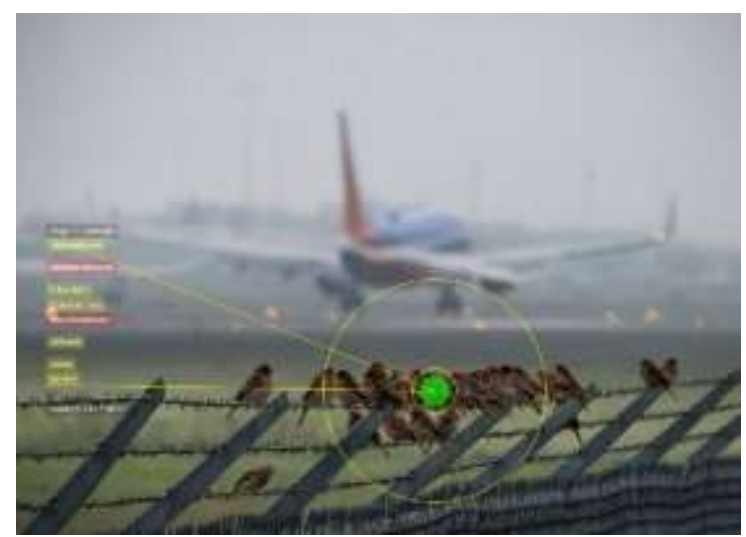

Gambar 1.11 Tampilan Visual Radar Mendeteksi Burung Bermigrasi 


\section{Keterangan :}

Pada gambar 1.11 adalah pengujian menggunakan dua image yang bersamaan yaitu gambar pesawat dan burung. Dari hasil pengujian sistem mampu mengenali objek burung yang hinggap secara berkelompok yang ada di area bandara. Burung berkolompok biasanya hidup dengan cara bermigrasi. Respon sistem selanjutnya adalah memberikan infomasi kepada pilot dan petugas bandara tentang posisi burung yang ada pada area lintasan dimasukan pada ketegori membahayakan atau tidak.

\section{KESIMPULAN}

Pada hasil pengujian sistem dapat diambil beberapa kesimpulan yaitu sistem deteksi burung pada area bandara dengan Vision Recognition dengan sistem radar bisa diimplementasikan secara bersamaan. Metode sistem kombinasi ini memiliki tingkat akurasi yang tinggi, sistem akan memberikan informasi kepada petugas bandara dan pilot pesawat untuk memcari waktu dan posisi yang tepat dalam mendaratkan atau menerbangkan pesawat, sementara petugas di darat atau grounding akan menggunakan sistem early warning system tersebut untuk membersihkan area. Saran untuk penelitian selanjutnya adalah menggunakan sistem dengan daya pandang kamera dan daya pancar yang lebih besar.

\section{DAFTAR RUJUKAN}

Desholm, M., et al. (2006). Remotetechniques for counting andestimating the number of birdwind turbine collisions at sea: a review. Ibis, 148, 76- 89.

Hans van Gasteren;Judy Shamoun-Baranes;Amnon Ginati;Giovanni Garofalo. (2009). AVIAN ALERT - A BIRD MIGRATION EARLY WARNING SYSTEM. Research Gate.

Holleman, I., H. van Gasteren, andW. Bouten,. (2008). Quality Assessment of Weather Radar Wind Profiles during Bird Migration. Journal of Atmospheric and Oceanic Technology.

Richardson, W.J. and T. West. (2000). military aircraft: updated list and summary, in Proceedings of the 25th International Bird Strike. Amsterdam, The Netherlands.

Richardson, W.J. and T. West,. (2005). Serious birdstrike accidents to U.K.military aircraft, 1923 to 2004. in Proceedings of the 27thInternational Bird Strike Committee, 1-19. 